\title{
Contribution of electrostatics in the fibril stability of a model ionic-complementary peptide
}

Marta Owczarz, Tommaso Casalini, Anna C. Motta, Massimo Morbidelli ${ }^{*}$ and Paolo Arosio ${ }^{\#}$

\section{Mass spectrometry}

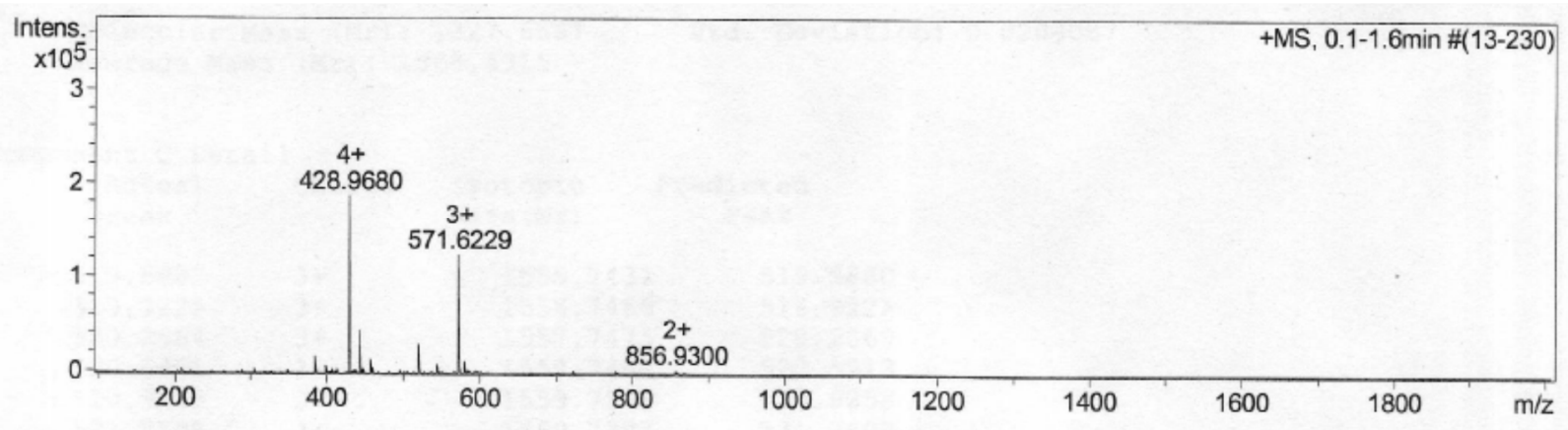

Figure S1. Mass spectrometry analysis of monomeric RADA 16-I. The monomeric peptide was separated by size exclusion chromatography running in $0.1 \%$ formic acid at $\mathrm{pH} 2.6$. For the details of the mass spectrometry analysis please refer to the Supplementary Information to the article by Arosio et al., Biophysical Journal, 2012.

\section{Convergence}

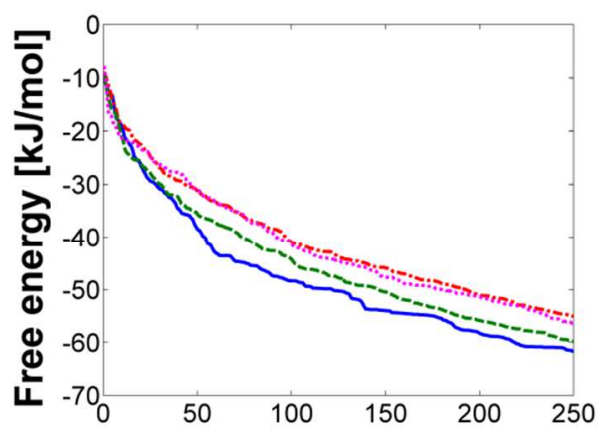

Simulation time per replica [ns]

Figure S2. Convergence of the free energy for RADA 16-I at pH 2.0 with $0 \mathrm{M}$ Gnd-HCl (blue, continoues line), $\mathrm{pH} 4.5$ with $0 \mathrm{M}$ Gnd-HCl (red, dash-dotted line), $\mathrm{pH} 2.0$ with $0.6 \mathrm{M}$ Gnd-HCl (green, dashed line) and $\mathrm{pH} 4.5$ with $0.6 \mathrm{M} \mathrm{Gnd}-\mathrm{HCl}$ (violet, dotted line). 


\section{Representative SEC Chromatograms}

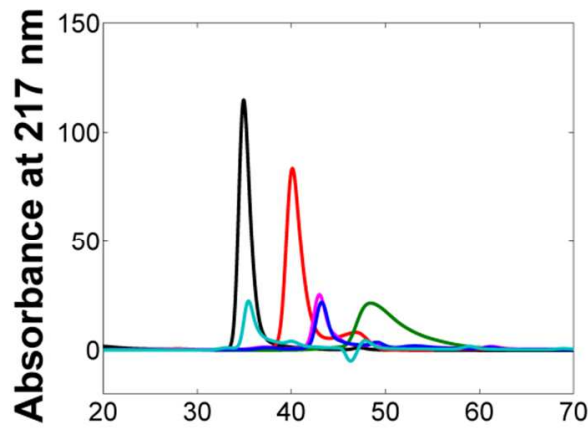

Elution time [min]

Figure S3. The SEC chromatograms of RADA 16-I at $0.5 \mathrm{~g} / \mathrm{L}$ in $10 \mathrm{mM} \mathrm{HCl}$ at $\mathrm{pH} 2.0$ (black line), $3.2 \mathrm{mM} \mathrm{HCl}$ at $\mathrm{pH} 2.5$ (red line), $10 \mathrm{mM}$ acetate buffer at $\mathrm{pH} 3.0$ (green line), $10 \mathrm{mM}$ acetate buffer at pH 3.5 (violet line), $10 \mathrm{mM}$ acetate buffer at $\mathrm{pH} 4.0$ (dark blue line) and $10 \mathrm{mM}$ acetate buffer at $\mathrm{pH} 4.5$ (light blue line).
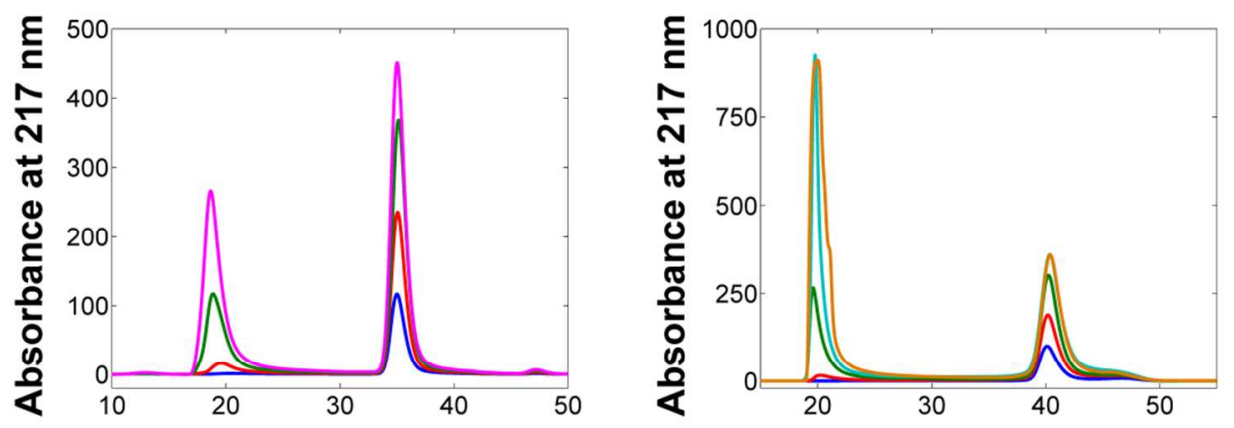

a

Elution time [min]

b

Elution time [min]
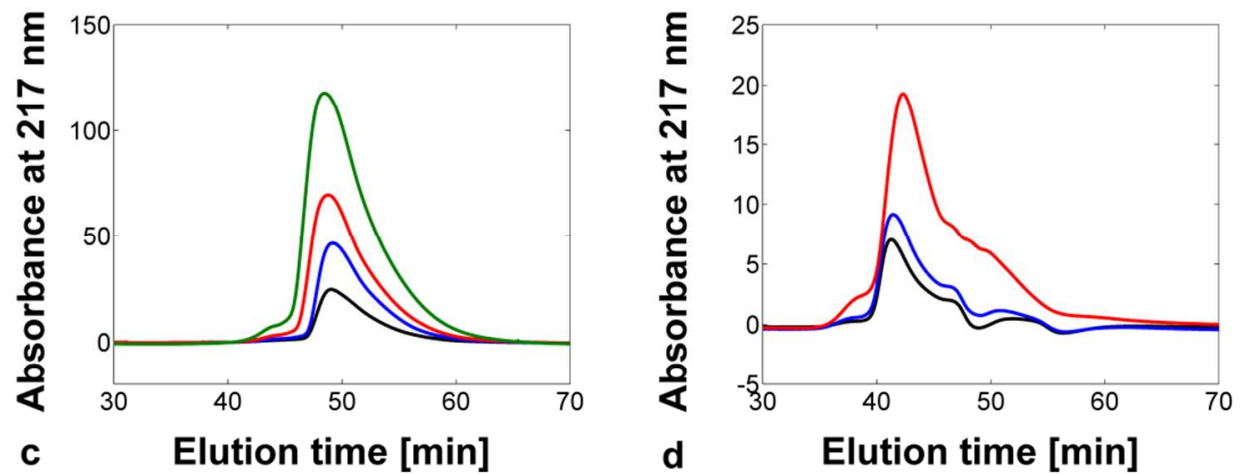

Figure S4. The SEC chromatograms of RADA 16-I at $0.25 \mathrm{~g} / \mathrm{L}$ (black line), $0.5 \mathrm{~g} / \mathrm{L}$ (dark blue line), $1 \mathrm{~g} / \mathrm{L}$ (red line), $2 \mathrm{~g} / \mathrm{L}$ (green line), $3 \mathrm{~g} / \mathrm{L}$ (violet line), $3.5 \mathrm{~g} / \mathrm{L}$ (light blue line) and $5 \mathrm{~g} / \mathrm{L}$ (orange line) in $10 \mathrm{mM} \mathrm{HCl}$ at $\mathrm{pH} 2.0$ (a), $3.2 \mathrm{mM} \mathrm{HCl}$ at $\mathrm{pH} 2.5$ (b), $10 \mathrm{mM}$ acetate buffer at pH 3.0 (c), and $10 \mathrm{mM}$ acetate buffer at $\mathrm{pH} 4.0$ (d). 

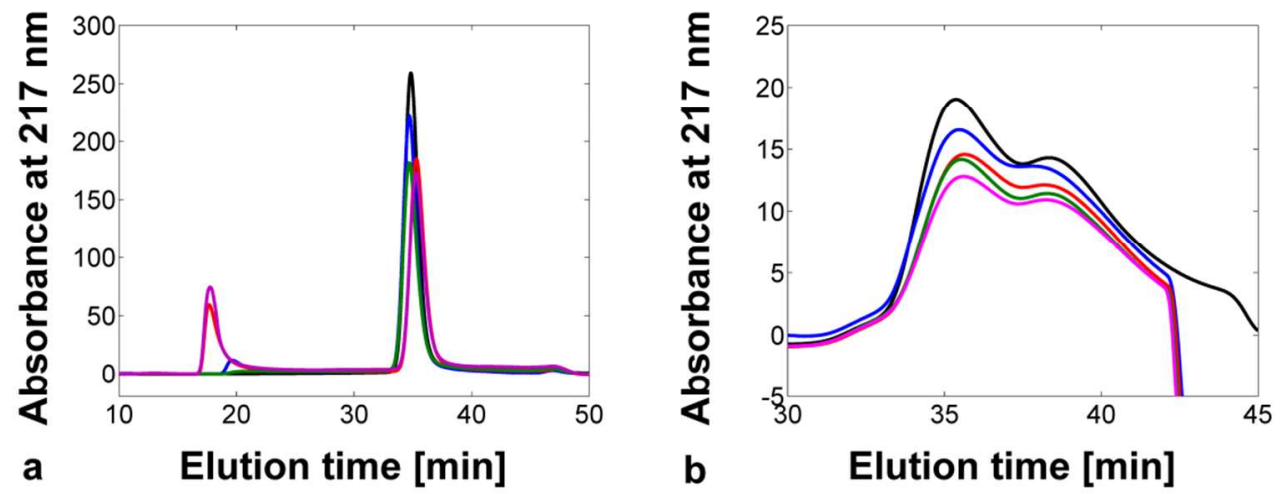

Figure S5. The SEC chromatograms of RADA 16-I at $1 \mathrm{~g} / \mathrm{L}$ in $10 \mathrm{mM} \mathrm{HCl}$ at pH 2.0 (a) and 10 $\mathrm{mM}$ acetate buffer at $\mathrm{pH} 4.5$ (b) containing $0 \mathrm{mM}$ (black line), $25 \mathrm{mM}$ (dark blue line), $50 \mathrm{mM}$ (red line), $75 \mathrm{mM}$ (green line) and $100 \mathrm{mM}$ (violet line) $\mathrm{NaCl}$.
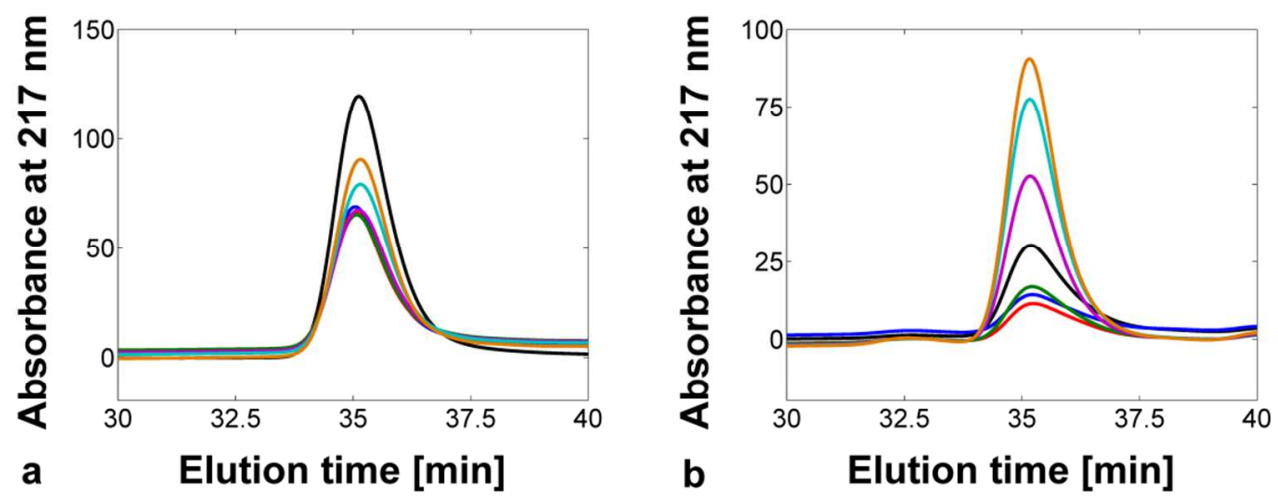

Figure S6. The SEC chromatograms of RADA 16-I at $1 \mathrm{~g} / \mathrm{L}$ in $10 \mathrm{mM} \mathrm{HCl}$ at pH 2.0 (a) and 10 $\mathrm{mM}$ acetate buffer at $\mathrm{pH} 4.5$ (b) in the absence (black line) and in the presence of $0.3 \mathrm{M}$ (dark blue line), 0.6 M (red line), $1 \mathrm{M}$ (green line), $2 \mathrm{M}$ (violet line), $4 \mathrm{M}$ (light blue line) and 6M (orange line) Gnd-HCl. 
a

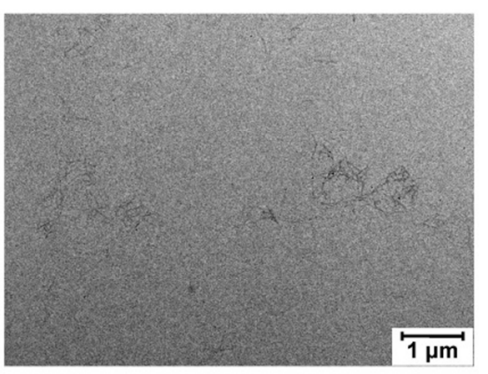

c

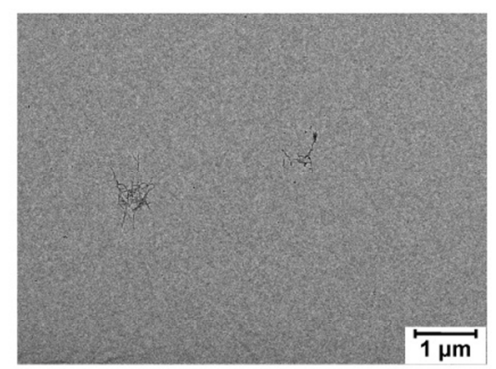

b

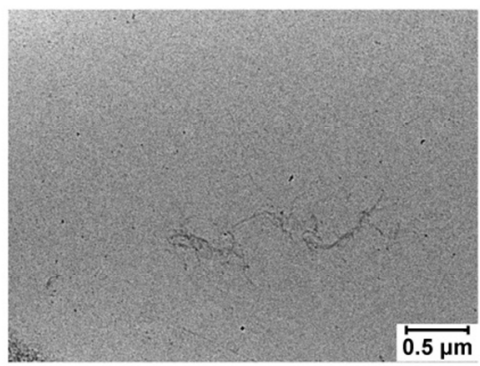

d

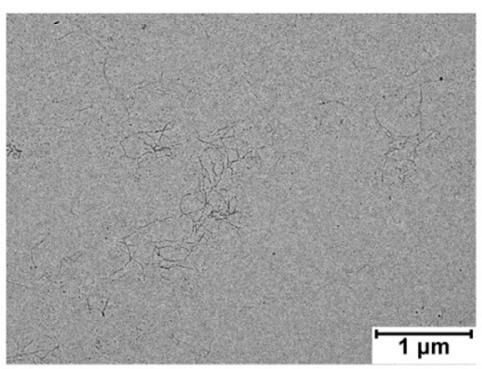

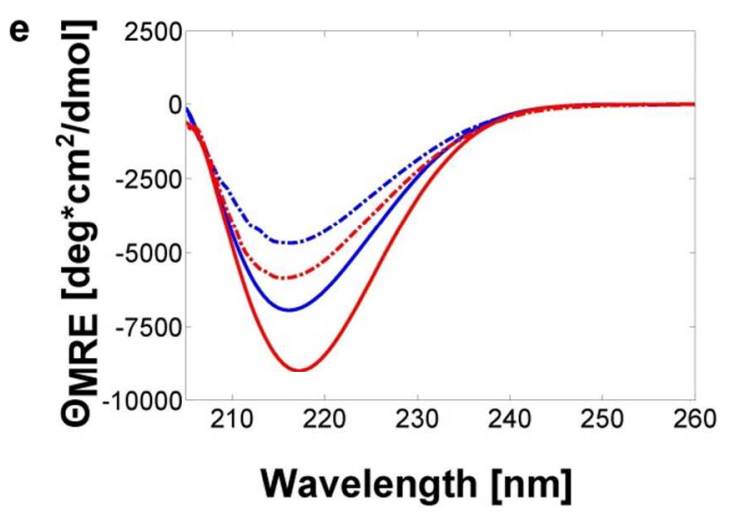

Figure S7. The guanidinium hydrochloride effect on the secondary structure and the morphology of RADA 16-I peptide. a-d) TEM pictures of the RADA 16-I solutions in $10 \mathrm{mM} \mathrm{HCl}$ at $\mathrm{pH} 2.0$ with $0.6 \mathrm{M}$ (a) and $6 \mathrm{M}$ (b) Gnd-HCl, $10 \mathrm{mM}$ acetate buffer at $\mathrm{pH} 4.5$ containing $0.6 \mathrm{M}$ (c) and 6 $\mathrm{M}$ (d) Gnd-HCl; e) CD spectra of $0.5 \mathrm{~g} / \mathrm{L}$ peptide solutions in $10 \mathrm{mM} \mathrm{HCl}$ at $\mathrm{pH} 2.0$ (blue lines), $10 \mathrm{mM}$ acetate buffer at $\mathrm{pH} 4.5$ (red lines) in the presence of $0.6 \mathrm{M}$ (continuous lines) and $6 \mathrm{M}$ Gnd-HCl (dash-dotted lines), showing the disruption of $\beta$-sheet structures with increasing the concentration of denaturant. 


\section{Free energy surface}
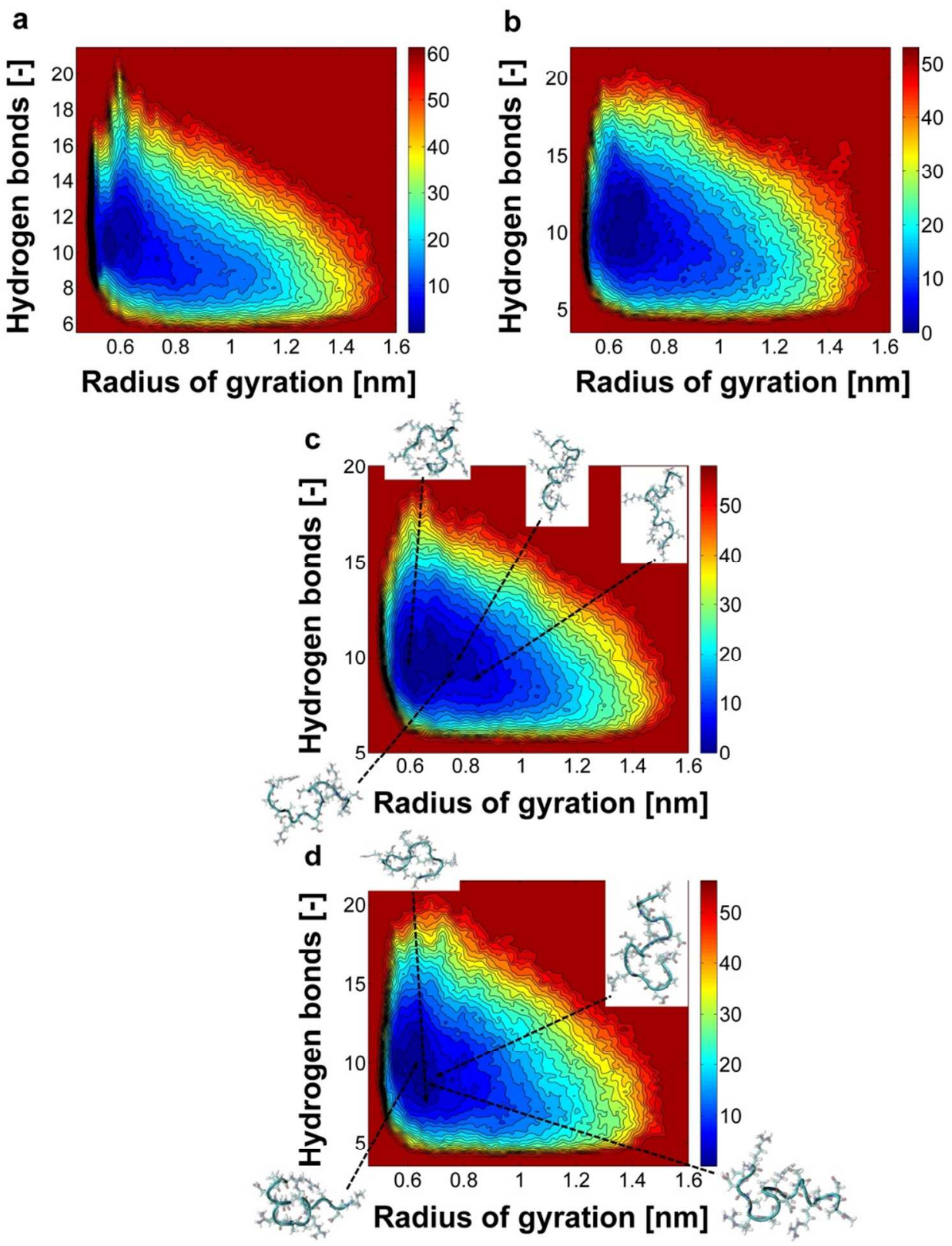

Figure S8. Free energy surface from PTMetaD-WTE at $\mathrm{pH} 2.0$ with $0 \mathrm{M}$ Gnd-HCl (a), $\mathrm{pH} 4.5$ with $0 \mathrm{M}$ Gnd-HCl (b), $\mathrm{pH} 2.0$ with $0.6 \mathrm{M} \mathrm{Gnd}-\mathrm{HCl}$ (c) and $\mathrm{pH} 4.5$ with $0.6 \mathrm{M}$ Gnd-HCl (d). Contour lines are plotted every $k_{B} T$ unit $(2.5 \mathrm{~kJ} / \mathrm{mol})$. 